\title{
Scietrey
}

\section{Antioxidant capacity of soybean protein isolate hydrolyzed with protease produced by Aspergillus 3.084 in vitro}

\section{Jinhuan Zong • Lijun Jiang • Shanfeng Chen • Chengye Ma • Hongjun Li • Dongliang Zhang}

School of Agricultural Engineering and Food Science, Shandong University of Technology, No. 12 Zhangzhou Road, Zhangdian District, Zibo, Shandong Province, China.

Accepted $6^{\text {th }}$ December, 2018.

\begin{abstract}
Aspergillus, being known as a protease producing fungi, is used in Chinese and Korean traditional fermentation. In this paper, Aspergillus 3.084, one of the most common fungi in China fermentation industry, was employed to produce protease and hydrolyze soybean protein, and then the optimum extraction condition of protease was determined by the antioxidant activities of protease extraction solution. The protease was extracted from the culture medium, and performed in hydrolyzing soybean protein isolation. Extract condition of protease, hydrolysis ability of proteases of Aspergillus in hydrolyzing soybean protein isolation and the antioxidant ability of hydrolysate were investigated by detecting enzyme activity, degree of hydrolysis, scavenging activities of $\mathrm{OH} \cdot \mathrm{O}_{2} \cdot{ }^{-}$and DPPH$\cdot$. Maximum protease activity was obtained at $60 \mathrm{~min}, \mathrm{pH} 7.5$ and $32^{\circ} \mathrm{C}$ in extraction step. Optimum protease hydrolyzing time, E/S, temperature and $\mathrm{pH}$ for degree of hydrolysis and scavenging activities was $3 \mathrm{~h}, 6000,37^{\circ} \mathrm{C}$ and 7.5 , respectively.
\end{abstract}

Keywords: Soybean protein, protease, Aspergillus 3.084, antioxidant activity.

\section{INTRODUCTION}

Soybean is a well-known source of protein with high protein and peptide content. Peptides made from soybean exhibit variety of functional properties, including immunomodulatory, antioxidant, anticancer (Lin et al., 2013). Fermentation, one of the oldest food-processing techniques, can improve the antioxidant properties of soybean through various biochemical transformations.

Aspergillus 3.084 is a common fungi in Chinese fermentation industry, it secretes amylase, glucoamylase, $\alpha$-amylase, alkaline protease, acid protease and neutral protease. The most familiar product made by Aspergillus is soybean paste, and the antioxidant capacity of soybean paste is given by fermentation process. This process also improved the properties of soybean by biochemical transformations including proteolysis, saccharification, esterification, etc (Rhyu and Kim, 2011). Soybean paste produced generally by two steps is a traditional seasoning in China and Korean, first step was pretreatment by steaming and shaping, fermentation was followed by microorganisms (Lee et al., 2014). In the beginning of fermentation processing, starter named qu in China and meju in Korean was added into pretreated soybean, which contained the microorganisms, including Bacillus, Aspergillus, Scopulariopsis, Cladosporium, Mucor, Lichtheimia, Rhizopus and Penicillium (Jung et al., 2014). Microorganisms have been identified in Korean meju, and Aspergillus was the main microorganism in china soybean paste (Wardhani et al., 2013). Soybean hydrolysates, such as amino acids and peptides, enriched the taste, flavor, even the antioxidant capacity of soybean paste. 
The antioxidant capacity test included hydroxyl free radical $(\mathrm{OH} \cdot)$ scavenging activity, 1,1-diphenyl-2-picrylhydrazylfree radical (DPPH-) scavenging activity and superoxide anion $\left(\mathrm{O}_{2 \cdot} \cdot{ }^{-}\right)$ scavenging activity. Superoxide radical is known to be harmful to cellular components as a precursor of more reactive oxidative species; it is also documented to play an important role in the peroxidation of lipids (Monod et al., 1991). Therefore, the scavenging activity on superoxide radicals is a way to investigate the antioxidant activity. Free radical is one of the factors that induce the pathogenesis of a wide range of age-related degenerative diseases through the oxidative modification of DNA, proteins and vital molecules (Malathi and Chakraborty, 1991; Cohen, 1973). DPPH, a stable radical-generating reagent, was used in the present study for primary screening of the antiradical activities (Yokozawa et al., 1998; Kalaskar et al., 2014). The main antioxidant properties was mainly given by the peptides, which was hydrolyzed by enzyme and acid. Protease secreted by Aspergillus 3.084 was employed to hydrolyze the soybean protein isolate, and the antioxidant properties of peptides, the enzymatic hydrolysate, was studied in this paper. Effects of temperature, $\mathrm{pH}$ value and ratio of enzyme/soybean protein powder ([E/S]) on the antioxidant properties of peptides hydrolyzed by extracted protease was investigated.

\section{MATERIALS AND METHODS}

\section{Materials}

Soybean protein powder (protein content of $80.2 \%$ ) was obtained from the valley of god biological technology group co., LTD (China). 2,2-Diphenyl-1-picrylhydrazyl (DPPH) and bull serum albumin (BSA) were purchased from Sigma Chemicals Co., LTD (USA).

\section{Protease preparation}

Aspergillus 3.084, obtained from Shandong wife food group co., LTD, Zibo, Shandong, was used in this study. The culture media were prepared with $20 \mathrm{~g}$ soybean meal, $20 \mathrm{~g}$ wheat bran and $10 \mathrm{~g}$ flour in $250 \mathrm{ml}$ erlenmeyer flasks and soaked with $50 \mathrm{~g}$ distilled water. Flask was mixed thoroughly and all flasks were autoclaved at $121^{\circ} \mathrm{C}$ for $20 \mathrm{~min}$, cooled to room temperature, inoculated with 1 $\mathrm{ml}$ of conidial inoculums $\left(1 \times 10^{9}\right)$, and then incubated at $32^{\circ} \mathrm{C}$ for $72 \mathrm{~h}$ (Belmessikh et al., 2013).

\section{Optimization of extract condition of protease}

Fermented substrate $(10 \mathrm{~g})$ was milled and mixed with 50 $\mathrm{ml} 0.1 \mathrm{~mol} / \mathrm{L} \mathrm{pH7.5}$ phosphate buffer and homogenized by ultrasound for 1 hour at $37^{\circ} \mathrm{C}$ to extract the enzyme.
Extraction condition under different $\mathrm{pH}$, temperature and time was optimized. Protease activity of the enzyme solution was analyzed by the method described by Lowry, enzyme-activity was micrograms of tyrosine produced by hydrolyzing the casein within one minute.

$\operatorname{Enzyme} \operatorname{activity}(U)=\frac{A}{T} \times N$

A, tyrosine $(\mu \mathrm{g})$

$\mathrm{T}$, time $(\mathrm{min})$

$\mathrm{N}$, dilution ratio

Total protein content of the extracted solution was measured by using coomassie brilliant blue staining with bovine serum albumin as a protein standard (de Castro and Sato, 2014).

\subsection{Peptide preparation}

Hydrolysis reaction was carried out under different temperature $\left(27,32,37,42,47^{\circ} \mathrm{C}\right)$, hydrolysis time $(1,2$, $3,4$ and $5 \mathrm{~h}), \mathrm{pH}(3.5,5.5,7.2,9$ and 10.5$)$ and ratio of enzyme/soybean protein ([E/S], 1000, 2000, 4000, 6000 and $8000 \mathrm{U}$ per gram soybean protein). The original temperature, hydrolysis time, $\mathrm{pH}$ and protease activity were set at $37^{\circ} \mathrm{C}, 2 \mathrm{~h}, 7.2$ and $25 \mathrm{U} / \mathrm{ml}$. After the hydrolysis reaction, solution was kept at $95^{\circ} \mathrm{C}$ for $3 \mathrm{~min}$ to inactivate the protease and cooled as the experimental group. Reaction solution $(10 \mathrm{ml})$ was adjusted to $\mathrm{pH} 8.2$ by $10 \mathrm{~mol} / \mathrm{L} \quad \mathrm{NaOH}$ or 10 $\mathrm{mol} / \mathrm{L} \mathrm{HCl}$ and diluted to $20 \mathrm{ml}$ for the determination of the degree of hydrolysis and, 10 reaction solution was adjusted to $\mathrm{pH} 7.0$ and diluted following the same step as above-mentioned for the other tests[14]. Mixture of enzyme and soybean protein was kept at $95^{\circ} \mathrm{C}$ for $3 \mathrm{~min}$ to inactivate the protease, which was unhydrolyzed solution and used for the control group.

\section{Determination of the degree of hydrolysis (DH) [15-17]}

Distilled water $(10 \mathrm{ml})$ was mixed with $10 \mathrm{ml}$ reaction solution, and then $20 \mathrm{ml} 36.5 \%$ formaldehyde solution (adjusted to $\mathrm{pH} 8.2$ with $0.1 \mathrm{~mol} / \mathrm{L} \mathrm{NaOH}$ ) was added (Castillo et al., 1962; Gould and Frantz, 1945; Mehler, 1957). The mixture solution was titrated to $\mathrm{pH} 9.2$ by 0.1 $\mathrm{mol} / \mathrm{L} \mathrm{NaOH}$, titration volume was $\mathrm{V}_{1}$. Unhydrolyzed solution $10 \mathrm{ml}$ (mixture of enzyme and soybean protein) was used for control, titration volume of which was $V_{2}$. The degree of protein hydrolysis was calculated as follows

Degree of protein hydrolysis\%

$$
=\left[\left(V_{1}-V_{2}\right) \times N /\left(C \times k \times V_{R}\right)\right] \times 100
$$

$\mathrm{V}_{1}$, consumption of $\mathrm{NaOH}$ for hydrolysis solution $(\mathrm{ml})$

$\mathrm{V}_{2}$, consumption of $\mathrm{NaOH}$ for control $(\mathrm{ml})$ 
$\mathrm{N}$, concentration of $\mathrm{NaOH}$ solution $(\mathrm{mol} / \mathrm{ml})$

$\mathrm{C}$, soybean protein concentration $(\mathrm{mg} / \mathrm{ml})$

$\mathrm{k}$, mol of peptide bonds per gram protein, $\mathrm{k}=7.75 \times 10^{-6}$ $\mathrm{mol} / \mathrm{mg}$ for the soybean protein

$V_{R}$, volume of reaction solution

\section{1,1-Diphenyl-2-picrylhydrazylfree radical (DPPH-) scavenging activity}

$\mathrm{DPPH} \cdot$ scavenging activity was estimated following the procedure, $2 \mathrm{ml}$ hydrolysate was added to $2 \mathrm{ml} 2 \mathrm{mmol} / \mathrm{L}$ $\mathrm{DPPH} \bullet$ (dissolved in absolute ethyl alcohol), after reacting for $30 \mathrm{~min}$ in dark, absorbance of the mixture was measured at $517 \mathrm{~nm}$. Also, an equal volume of each sample was mixed with $2 \mathrm{ml}$ absolute ethanol but without $\mathrm{DPPH} \cdot$ as control to avoid interference of protein and peptide[18], $2 \mathrm{ml}$ distilled water was mixed with2 $\mathrm{ml} 2$ $\mathrm{mmol} / \mathrm{L}$ DPPH $\cdot$ (dissolved in absolute ethyl alcohol) for the absorbance of $\mathrm{DPPH} \bullet$, and $2 \mathrm{~mL}$ unhydrolyzed solution mixed with $2 \mathrm{ml}$ of $2 \mathrm{mmol} / \mathrm{L} \mathrm{DPPH} \bullet$ (dissolved in absolute ethyl alcohol) for the absorbance of control group. The scavenging percentage of hydrolyzed solution on $\mathrm{DPPH} \cdot$ was calculated according to the following equation[19].

Scavenging percentage of $D P P H \bullet \%$

$$
=\left[\left(A_{C}-A_{H}\right) / A_{B}\right] \times 100
$$

$A_{c}$, absorbance of control group

$\mathrm{A}_{\mathrm{H}}$, absorbance of hydrolysate

$\mathrm{A}_{\mathrm{B}}$, absorbance of DPPH $\bullet$ (blank group)

\section{Superoxide anion $\left(\mathrm{O}_{2 \cdot}{ }^{-}\right)$scavenging activity}

All experiments were performed at $25^{\circ} \mathrm{C}$, the assay medium $(0.05 \mathrm{~mol} / \mathrm{L}$ TRIS buffer, $\mathrm{pH} 8.2) 4.5 \mathrm{ml}$ mixed with $100 \mu \mathrm{l}$ hydrolyzed solution and $400 \mu \mathrm{l} 2.5 \mathrm{mmol} / \mathrm{L}$ pyrogallol, stopped reaction $4 \mathrm{~min}$ later with $0.1 \mathrm{ml} 10$ $\mathrm{mol} / \mathrm{L} \mathrm{HCl}$ and recorded at $325 \mathrm{~nm}$. Also, $100 \mu \mathrm{l}$ distilled water was used in blank group, and $100 \mu$ l unhydrolyzed solution replaced hydrolyzed solution in control group. The scavenging percentage of hydrolyzed solution on $\mathbf{O}_{2}{ }^{*}$ was calculated according to the following equation.

Scavenging percentage of $\boldsymbol{O}_{2}^{--} \%=\left[\left(A_{C}-A_{H}\right) / A_{B}\right] \times 100$

Ac, absorbance of control group

$\mathrm{A}_{\mathrm{H}}$, absorbance of hydrolysate

$A_{B}$, absorbance of $\mathbf{O}_{2^{-}}{ }^{-}$(blank group)

\section{Hydroxyl free radical $(\mathrm{OH} \cdot)$ scavenging activity}

The assay for hydroxyl radical $(\mathrm{OH} \bullet)$ was determined using the methods of Wang et al. The $\mathrm{OH} \bullet$ in aqueous media is generated through the Fenton reaction, reaction mixture contained $0.24 \mathrm{~mol} / \mathrm{L}$ K-phosphate buffer $(\mathrm{pH} 7.4)$, $1.0 \mathrm{mmol} / \mathrm{L}$ salicylic acid, $0.3 \mathrm{mM} \mathrm{FeSO} / \mathrm{EDTA}_{4}(4 \mathrm{mmol} / \mathrm{L})$, $0.8 \mathrm{mmol} / \mathrm{L} \mathrm{H}_{2} \mathrm{O}_{2}$, and $100 \mu \mathrm{l}$ of hydrolysate. Distilled water $(100 \mu \mathrm{l})$ was used in blank group, and unhydrolyzed solution $(100 \mu \mathrm{l})$ replaced hydrolysate in control group. The scavenging percentage of hydrolyzed solution on $\mathrm{OH} \cdot$ was calculated according to the following equation.

$$
\begin{aligned}
& \text { Scavenging percentage of } \mathrm{OH} \bullet \% \\
& =\left[\left(A_{C}-A_{H}\right) / A_{B}\right] \times 100
\end{aligned}
$$

Ac, absorbance of control group

$\mathrm{A}_{\mathrm{H}}$, absorbance of hydrolysate

$\mathrm{A}_{\mathrm{B}}$, absorbance of $\mathrm{OH} \cdot($ blank group)

\section{RESULTS}

\section{Protease preparation}

Aspergillus 3.084 grew on potato agar medium with yellow mature spores in the middle part of fungi colony (Figure 1A). When Aspergillus grow and secreted the enzyme, medium beside the Aspergillus became more transparent for culture medium contained $1 \%$ casein and enzyme hydrolyzed casein to make this vitrification. Figure 1B was fermented substrate, fungi covered the surface and grow inside the substrate.

Optical density of tyrosine in the enzyme activity detection of extracted solution and the linear trend line of OD and tyrosine concentration (correlation between OD and tyrosine concentration) was Figure 2, the enzyme activity of solution was obtained.

\section{Optimization of extract condition of protease}

Fermentation production was extraction with different condition included time, temperature and $\mathrm{pH}$ to investigate the optimal extract condition, and $60 \mathrm{~min}, \mathrm{pH}$ 7.5 and $32^{\circ} \mathrm{C}$ were performed in this step (Figure 3 ).

\section{DH and antioxidant activity under different E/S}

$\mathrm{DH}$ increased following the increase of $\mathrm{E} / \mathrm{S}$ (decrease of substrate concentration), even the same trend appeared in DPPH • scavenging activity of hydrolyzed soybean protein. DPPH • scavenging activity was less steep than $\mathrm{DH}$, the values were between 13 to 19.5. Small molecular weight proteins and peptides generated following the E/S increase, which had higher DPPH• scavenging activity 

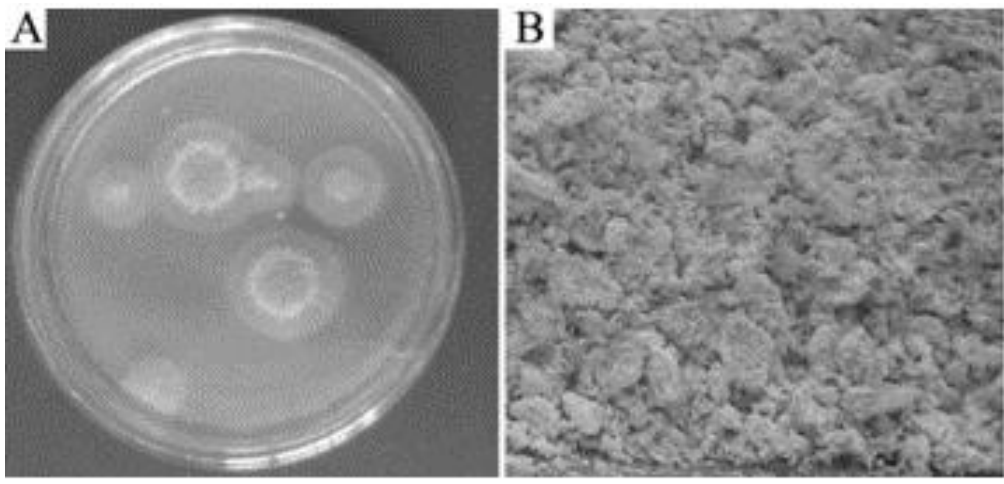

Figure 1. A. Aspergillus 3.084 grow on culture dish, B. fermented substrate.

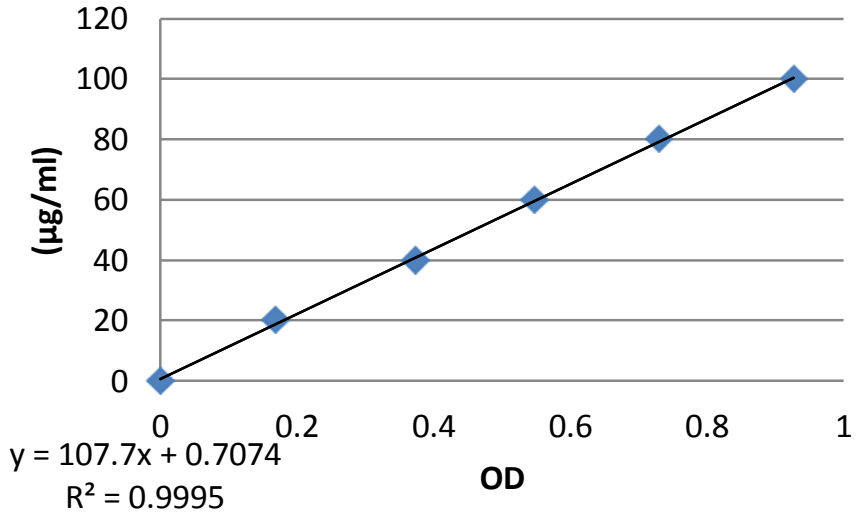

Figure 2. Standard curve of OD and tyrosine concentration.

(Figure 4).

$\mathrm{O}_{2}{ }^{--}$and $\mathrm{OH} \bullet$ scavenging activities declined, and the trend of $\mathrm{O}_{2}{ }^{-}$scavenging activity was slower than $\mathrm{OH} \cdot$ scavenging activity. Soybean protein hydrolyzed by protease to small molecular weight protein and peptide, more of that were produced in low substrate concentration (high E/S). This result means that small molecular weight proteins and peptides had stronger $\mathrm{O}_{2^{\circ}}$ and $\mathrm{OH}^{\circ}$ scavenging ability (Figure 4).

\section{DH and antioxidant activity under different reaction time}

The $\mathrm{DH}$ and antioxidant activities of hydrolyzate solution were monitored every $1 \mathrm{~h}$ up to $5 \mathrm{~h}$ by mixture of soybean protein and proteases solution at $6000 \mathrm{E} / \mathrm{S}$. Curves of $\mathrm{DH}$, $\mathrm{DPPH} \cdot$ scavenging activity, $\mathrm{O}_{2} \cdot{ }^{-}$scavenging activity and $\mathrm{OH}$. scavenging activity showed rising trend following reaction time (Ortiz and An, 2000), which suggested that scavenging activities increased with the $\mathrm{DH}$ (Figure 5). B.P. Lamsal depicted that the subunits of $\beta$-conglycinins, and acidic and basic subunits of glycinin, almost entirely disappeared hydrolysate at $2 \% \mathrm{DH}$ of soybean protein isolation (Lamsal et al., 2007), and then small molecular weight peptides and amino acids were obtained. Among those hydrolyzed peptides and amino acids, several kinds of them in soybean hydrolysate had antioxidant activity which was obtained from the hydrolyzed bitter peptides.

\section{DH and antioxidant activity under different temperature}

Those detected indexes had the same trend following the increase of temperature (Figure 6). Low DH was detected in high temperature for the induction of protease inactivation and protein denaturation, and antioxidant activities were also decreased with the $\mathrm{DH}$. Antioxidant activities were lower in low temperature than high, coincided with trend of $\mathrm{DH}$.

\section{$\mathrm{DH}$ and antioxidant activity under different $\mathrm{pH}$}

Extracted enzyme solution contained many kinds of proteases with the optimum reaction $\mathrm{pH}$ of this solution was 7.5. Antioxidant activities varied following the change of $\mathrm{DH}$, and low values measured at two extreme points (Figure 7). Acid protease included in solution had optimum 


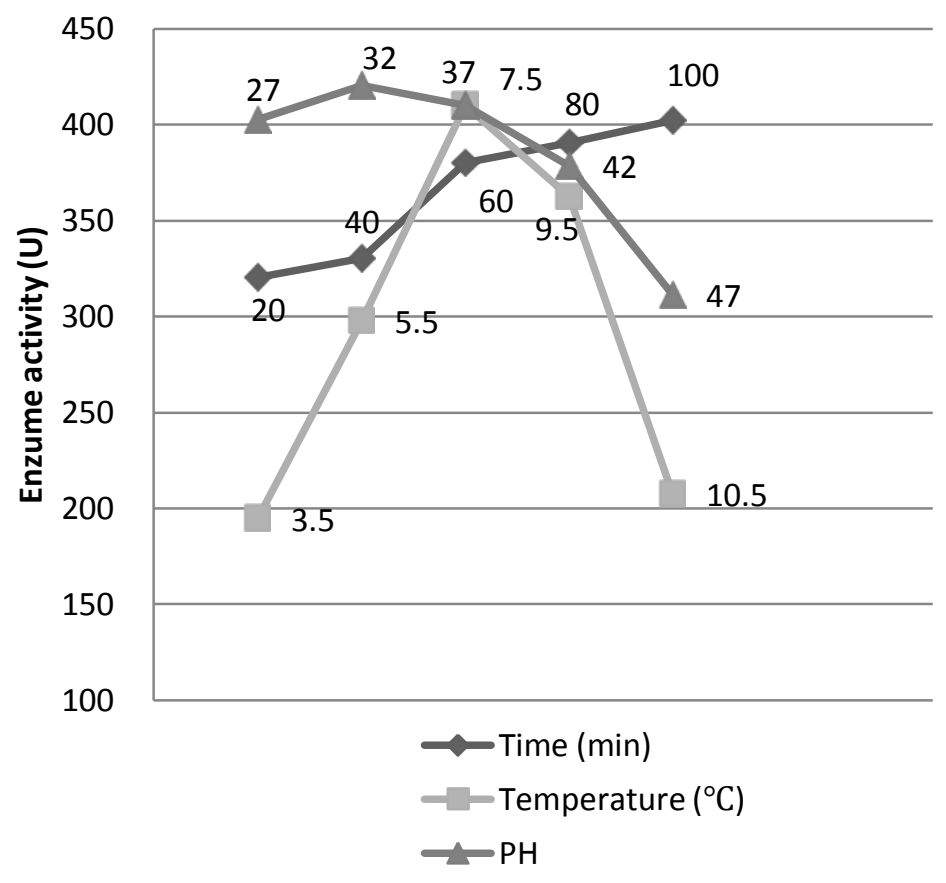

Figure 3. Curves of enzyme activity.

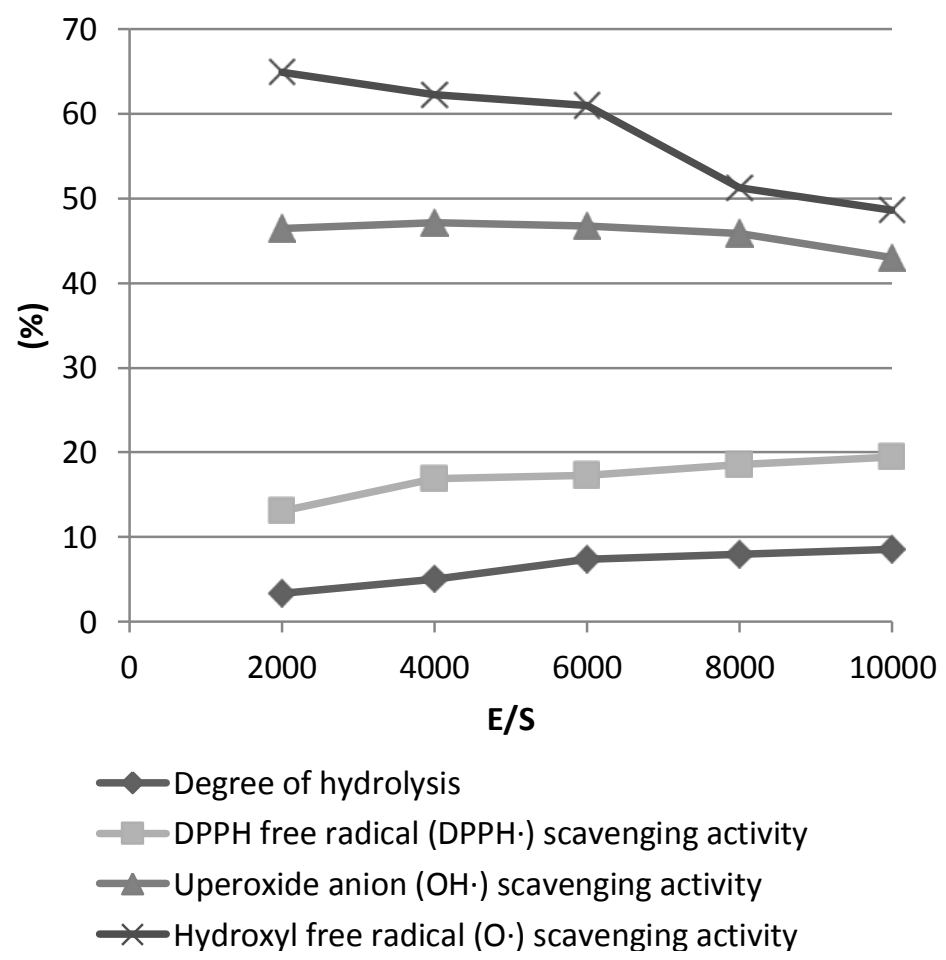

Figure 4. Trends of DH and DPPH $\bullet, \mathrm{O}_{2}{ }^{\bullet}, \mathrm{OH} \bullet$ scavenging activities at different $\mathrm{E} / \mathrm{S}$.

action $\mathrm{pH}$ at or nearly 3 with its lower hydrolysis ability than alkaline protease at its optimum $\mathrm{pH} 10.5$. Middle protease also had enzyme activity at $\mathrm{pH} 9$ and 5.5, which contributed to the high antioxidant activities. Even the $\mathrm{DH}$ at $\mathrm{pH} 3$ was more than double times at $\mathrm{pH} 7.5$ and 9 nearly double times at $\mathrm{pH} 5.5$, there was no so much difference between the oxidant activities at $\mathrm{pH} 3$ and $\mathrm{pH}$ $5.5,7.5$ and 9. 
Int. J. Biotechnol. Food Sci. / Zong et al.
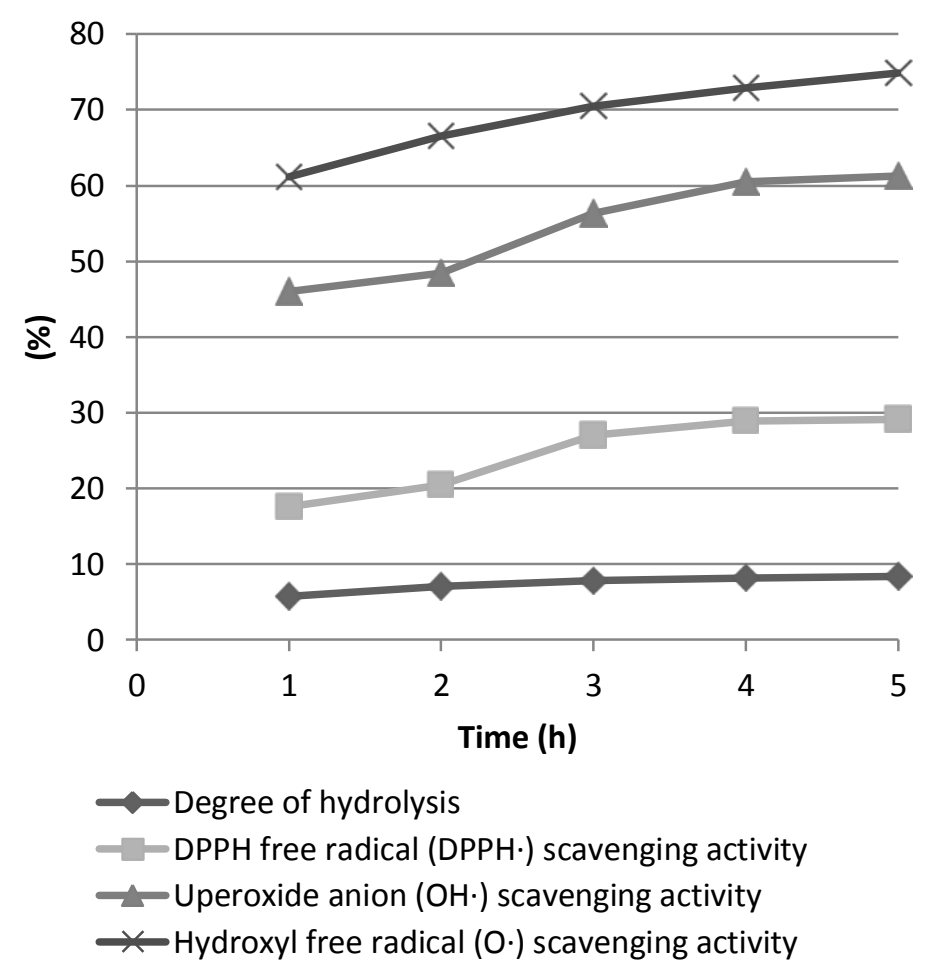

Figure 5. Trends of $\mathrm{DH}$ and $\mathrm{DPPH} \bullet, \mathrm{O}_{2}{ }^{\bullet}, \mathrm{OH} \bullet$ scavenging activities under different reaction time.

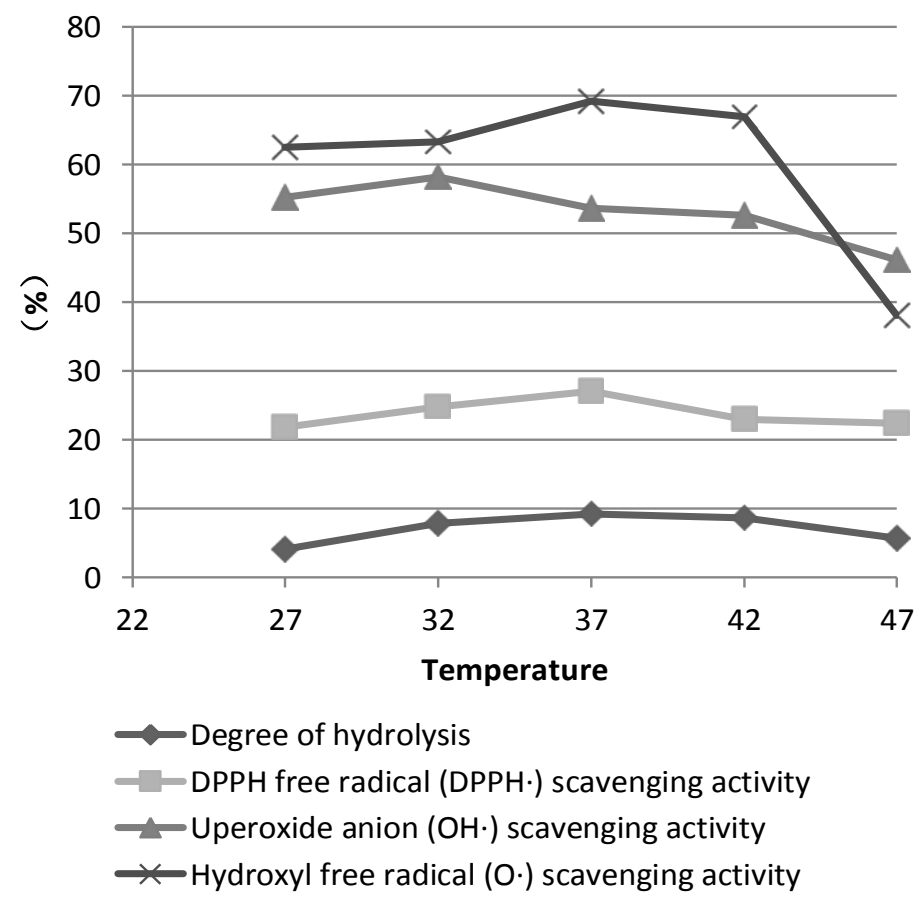

Figure 6. Trends of DH and DPPH•, $\mathrm{O}_{2}{ }^{\bullet}, \mathrm{OH} \bullet$ scavenging activities at different temperature.

Enzyme produced by Aspergillus 3.084 contained multiple kinds of proteases, classifying as alkaline, neutral and acid protease, they had their own optimal pH. Ph 7.5 indicated that neutral protease activity was higher than 


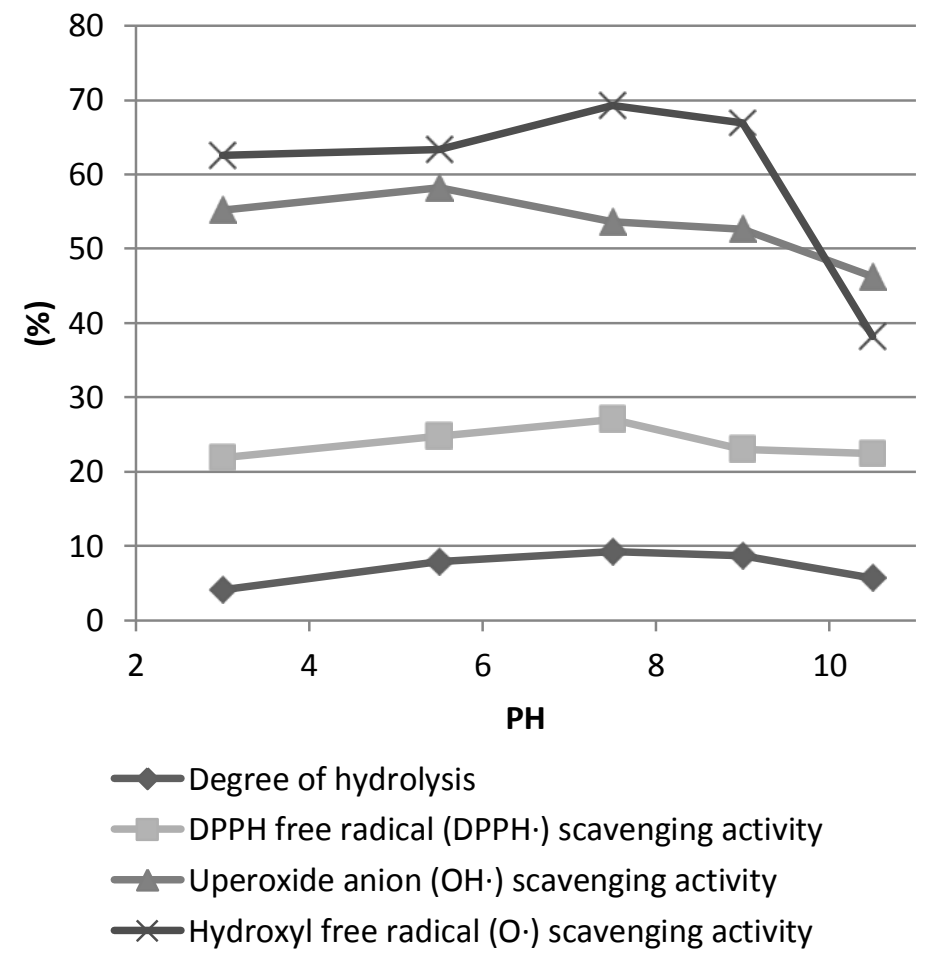

Figure 7. Trends of $\mathrm{DH}$ and $\mathrm{DPPH} \bullet, \mathrm{O}_{2}{ }^{-}, \mathrm{OH} \bullet$ scavenging activities at different $\mathrm{pH}$.

other two, alkaline and acid protease could not reach the same hydrolysis ability even in the optimal $\mathrm{pH}$.

\section{CONCLUSIONS}

Action of different kind of protease on soybean protein was different[20], Aspergillus production contained many kinds of proteases which had different extracting properties, hydrolyzing abilities[10]. Longer extracting time give the solution higher enzyme activity following the increasing dissolved enzyme, and enzyme activity reached the top point at $\mathrm{pH} 7.5$ and $37^{\circ} \mathrm{C}$, This result indicated that the middle protease played the most important part in enzyme activity of this solution.

Optimum reaction time, $\mathrm{E} / \mathrm{S}$, temperature and $\mathrm{pH}$ was 3 $\mathrm{h}, 6000,37^{\circ} \mathrm{C}$ and 7.5 , following the $\mathrm{DH}$, antioxidant activities of this solution reached the maximum point at the same reaction conditions. Soybean proteins hydrolyzed by limited or controlled enzyme could provide ingredients with desired peptides and functionalities (Lamsal et al., 2007), Aspergillus 3.084 with multifarious proteases used in traditional fermentation technology contributed to the peculiar flavor of production composed by different hydrolyzed ingredients (Han et al., 2001; Zhao et al., 2006; Zhao et al., 2009). Rising trend of DH was slower after $3 \mathrm{~h}$ hydrolysis than before. It reached the top point at $5 \mathrm{~h}$ within given time interval, and longer time enhanced the $\mathrm{DH}$ and facilitated the peptides production. Higher $\mathrm{DH}$ and antioxidant properties were obtained in industrial manufacture for it had longer fermentation time.

\section{ACKNOWLEDGEMENT}

This work was supported by the Shandong Provincial Natural Science Foundation, China (ZR2017MC073).

\section{REFERENCES}

Lin S, Wang J, Zhao P, Pang Y, Ye H, Yuan Y, Liu J, Jones G (2013). Optimized antioxidant peptides fractions preparation and secondary structure analysis by MIR. Int. J. Biol. Macromol. 59(0):151-157.

Rhyu MR, Kim EY (2011). Umami taste characteristics of water extract of Doenjang, a Korean soybean paste: Low-molecular acidic peptides may be a possible clue to the taste. Food Chem. 127(3):1210-1215.

Lee SY, Lee S, Lee S, Oh JY, Jeon EJ, Ryu HS, Lee CH (2014). Primary and secondary metabolite profiling of doenjang, a fermented soybean paste during industrial processing. Food Chem. 165(0):157-166.

Jung JY, Lee SH, Jeon CO (2014). Microbial community dynamics during fermentation of doenjang-meju, traditional Korean fermented soybean. Int. J. Food Microbiol. 185(0):112-120.

Wardhani DH, Fuciños P, Vázquez JA, Pandiella SS (2013). Inhibition kinetics of lipid oxidation of model foods by using antioxidant extract of fermented soybeans. Food Chem. 139(1-4):837-844.

Monod M, Togni G, Rahalison L, Frenk E (1991). Isolation and characterization of an extracellular alkaline protease of Aspergillus fumigatus. J. Med. microbiol. 35(1):23-28.

Malathi S, Chakraborty R (1991). Production of alkaline protease by a new Aspergillus flavus isolate under solid-substrate fermentation conditions for use as a depilation agent. Appl. Environ. Microbial. 57(3):712-716.

Cohen B (1973). Regulation of intracellular and extracellular neutral and 
alkaline proteases in Aspergillus nidulans. J. General Microbiol. 79(2):311-320.

Yokozawa T, Chen CP, Dong E, Tanaka T, Nonaka GI, Nishioka I (1998). Study on the inhibitory effect of tannins and flavonoids against the 1, 1-diphenyl-2-picrylhydrazyl radical. Biochem. Pharmacol. 56(2):213-222.

Kalaskar VV, Narayanan K, Subrahmanyam VM, Rao JV (2014) Optimization of Extracellular Acid Protease Production from Aspergillus Niger by Factorial Design. J. Microbiol. Biotechnol. Food Sci. 4(2):132-136.

Belmessikh A, Hayet B, Mechakra-Maza A, Gheribi-Aoulmi Z, Abdeltif A (2013). Statistical optimization of culture medium for neutral protease production by Aspergillus oryzae. Comparative study between solid and submerged fermentations on tomato pomace. J. Taiwan Instit. Chem. Eng. 44(3):377-385.

de Castro RJS, Sato HH (2014). Advantages of an acid protease from Aspergillus oryzae over commercial preparations for production of whey protein hydrolysates with antioxidant activities. Biocatal. Agric. Biotechnol. 3(3):58-65.

Castillo LS, Trimberger GW, Henderson CR, Herrington BL, Turk KL (1962). Comparison of Orange G Dye, Formol Titration, and Kjeldahl Methods for Milk Protein Determinations. J. Dairy Sci. 45(9):1079-1082.

Gould IA, Frantz RS (1945). Some Relationships between pH, Titrable Acidity, and the Formol Titration in Milk Heated to High Temperatures. J. Dairy Sci. 28(5):387-399.
Mehler AH (1957). Chapter ii - Hydrolysis of peptides and proteins, in Introduction to Enzymology, A.H. Mehler, Editor. Academic Press. pp. 13-36.

Ortiz SEM, An MC (2000). An, Analysis of products, mechanisms of reaction, and some functional properties of soy protein hydrolysates. J. Am. Oil Chemists' Soc. 77(12):1293-1301.

Lamsal B, Jung S, Johnson L (2007). Rheological properties of soy protein hydrolysates obtained from limited enzymatic hydrolysis. LWT-Food Sci. Technol. 40(7):1215-1223.

Han BZ, Rombouts FM, Nout M (2001). A Chinese fermented soybean food. Int. J. Food Microbiol. 65(1):1-10.

Zhao J-X, Gu X-H, Liu Y-M, Wang L-P (2006). Study on the Volatile Flavor Compounds of the Traditional Chinese Soybean Paste. J. Food Sci. 12:178

Zhao J-x, DAl X-J, Tian F-W, Zhang H, Tang J, Chen W (2009). GC-olfactometric Analysis of Flavor Compounds in Traditional Soybean Paste. J. Food Sci. 20:094.

http://www.sciencewebpublishing.net/ijbfs 